\title{
Socket shield technique: A systematic review of human studies
}

\author{
Luis Miguel Sáez-Alcaide ${ }^{\mathrm{a}, *}$, Francisco González Fernández-Tresguerres a , \\ Jorge Cortés-Bretón Brinkmann ${ }^{\mathrm{a}}$, Luis Segura-Mori ${ }^{\mathrm{b}}$, Oscar Iglesias-Velázquez ${ }^{\mathrm{a}}$, \\ Fabián Pérez-González a ${ }^{a}$ Rosa María López-Pintor ${ }^{a}$, Jesús Torres García-Denche ${ }^{\text {a }}$ \\ a Department of Dental Clinical Specialties, Faculty of Dentistry, Complutense University of Madrid, Spain \\ b Department of Conservative Dentistry and Orofacial Prosthodontics, Faculty of Dentistry, Complutense University of Madrid, Spain
}

\section{A R T I C L E I N F O}

\section{Article history:}

Received 25 December 2020

Received in revised form 13 May 2021

Accepted 17 May 2021

Available online 1 June 2021

\section{Keywords:}

Socket shield technique

Partial extraction therapies

Dental implants

\begin{abstract}
A B S T R A C T
Background and Purpose: Alveolar bone resorption after dental extraction frequently leads to situations in which long-term function and esthetic success of rehabilitations with dental implants is a challenge. Socket shield has been described as an alternative technique to maintain the alveolar ridge when placing immediate implants. The aim of this review is to evaluate the medium- and long-term clinical outcomes of the socket shield technique in human studies.

Material and Methods: This review was conducted according to PRISMA guidelines. An electronic search was conducted in four databases: (1) The National Library of Medicine (MEDLINE/PubMed) via Ovid; (2) Web of Science (WOS); (3) SCOPUS; and (4) Cochrane Central Register of Controlled Trials (CENTRAL). The Cochrane Collaboration tool, the Newcastle-Ottawa Quality Assessment Scale and The Joanna Briggs Institute Critical Appraisal tool were used to assess the quality of evidence in the studies reviewed. Results: Six articles were included in this review. The studies analysed showed lower rates of horizontal and vertical alveolar bone resorption, better maintenance of the buccal plate, less marginal bone loss and better esthetic results than simple placement of immediate implants. However, a lack of homogeneity was found in evaluation methods of the different outcomes, surgical procedures and prosthetic management. Conclusions: Based on the results of this review, it is possible to suggest that socket shield technique could be a good alternative in terms of alveolar bone maintenance, marginal bone stability and aesthetic outcomes in immediate implant treatment. However, it is not possible to recommend this technique as an alternative treatment with the same long-terms predictability as conventional immediate implants.

(C) 2021 The Authors. Published by Elsevier GmbH. This is an open access article under the CC BY-NC-ND license (http://creativecommons.org/licenses/by-nc-nd/4.0/).
\end{abstract}

\section{Contents}

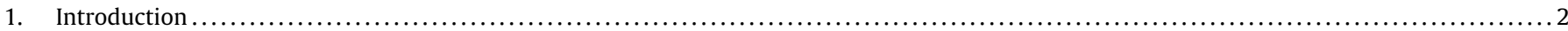

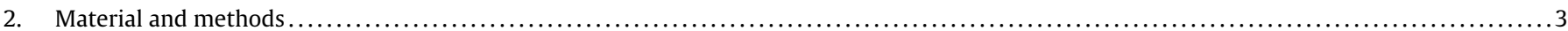

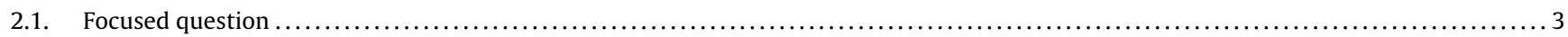

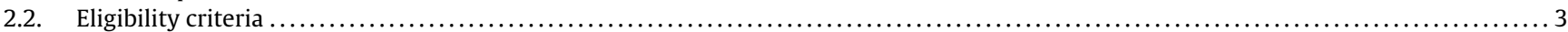

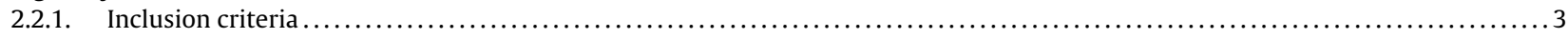

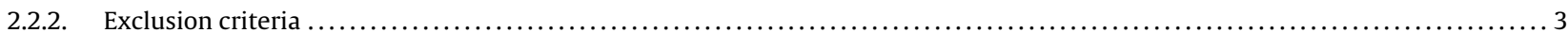

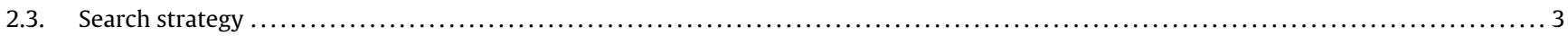

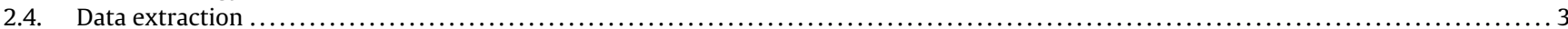

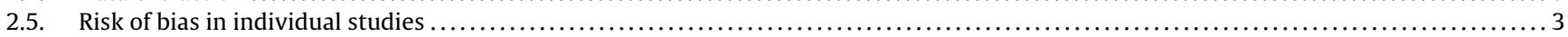

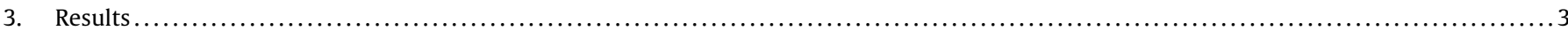

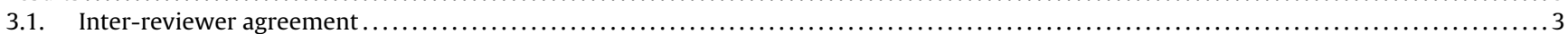

Abbreviations: mm, millimeter; SS, Socket-shield; PET, Partial Extraction Therapies; CBCT, Cone Beam Computed Tomography; RCT, Randomized Clinical Trial; PEFS, Pink Esthetic Furhauser Scale; PRF, Platelet-Rich Fibrin; MBL, Marginal Bone Loss.

is This paper belongs to the special issue Dentistry 2021.

* Corresponding author.

E-mail address: lsaez@ucm.es (L.M. Sáez-Alcaide). 


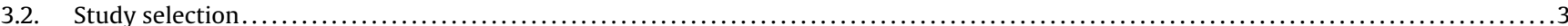

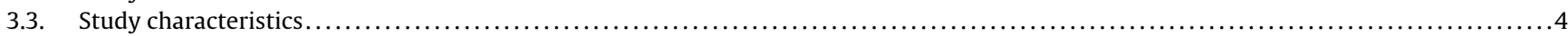

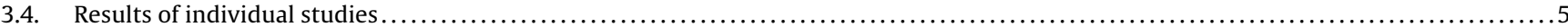

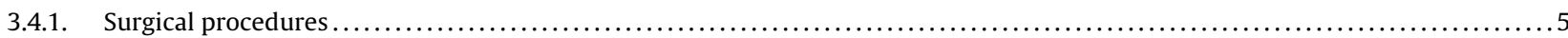

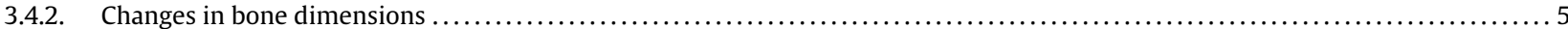

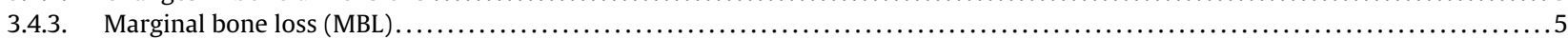

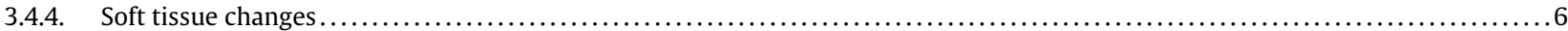

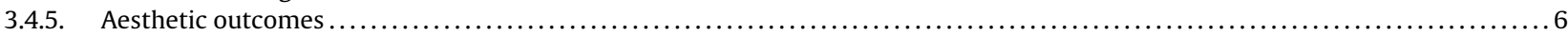

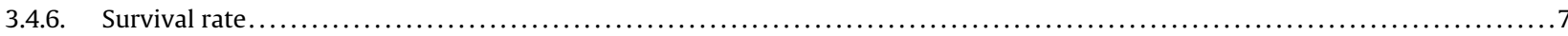

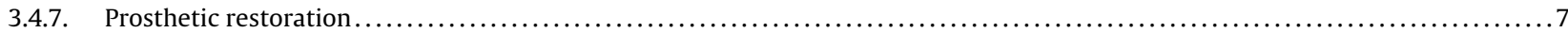

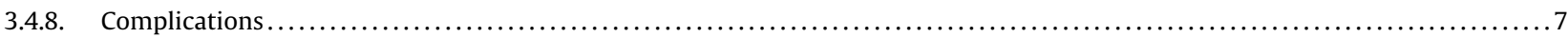

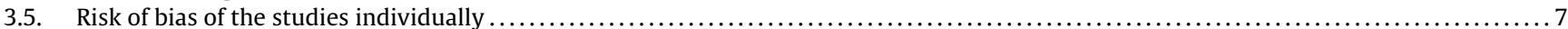

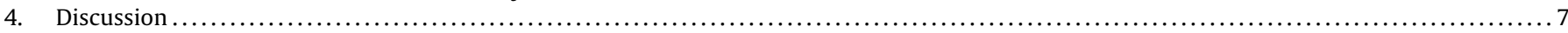

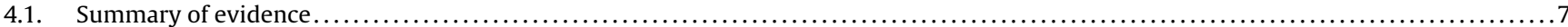

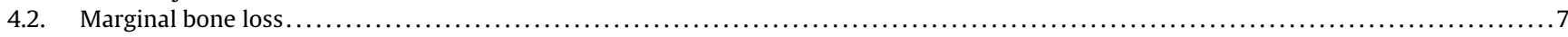

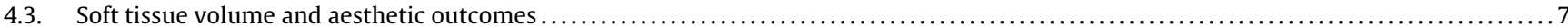

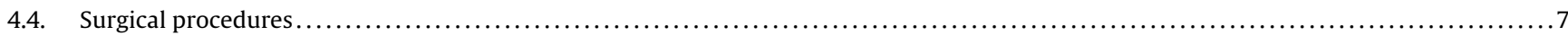

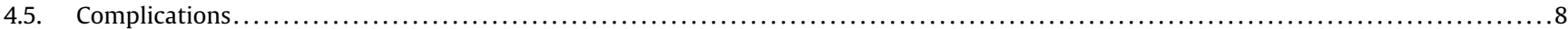

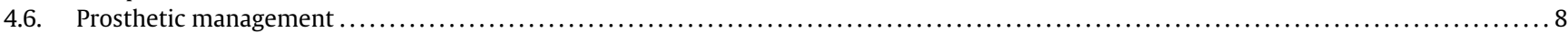

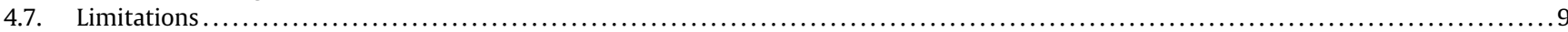

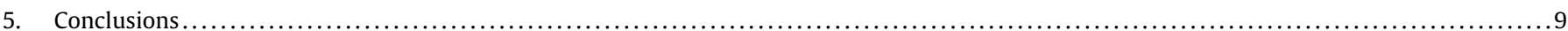

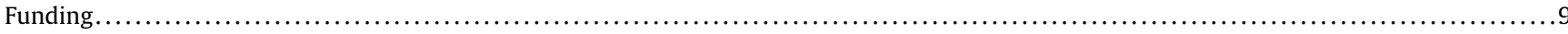

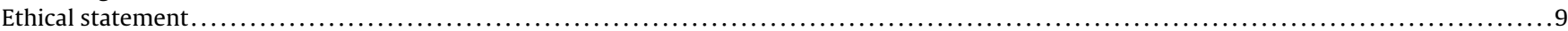

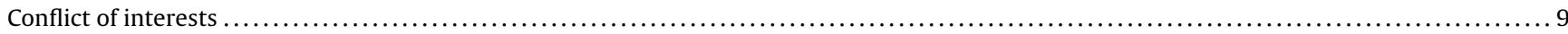

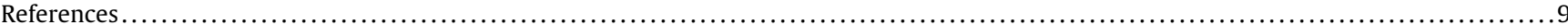

\section{Introduction}

Alveolar bone, tooth, cement and periodontal ligament constitute a functional unit. In this way, when a tooth is lost, this functional unit is disrupted, leading to an unavoidable resorption of the alveolar ridge (Araújo et al., 2015).

Several studies have demonstrated that a $50 \%$ of the alveolar width is reabsorbed in the first 12 months after the extraction of a tooth, corresponding to an average of 5-7 mm. Elsewhere, it is estimated that two-thirds of this resorption occurs in the first 3 months, mainly in the buccal plate, due to its lower thickness (Schropp et al., 2003; Araújo and Lindhe, 2005). Thus, the morphology of the alveolar ridge after tooth extraction can present a discrepancy in bone height between the lingual and buccal plate (Araújo et al., 2015; Lang et al., 2012).

Nowadays, there is an increase in patients who require immediate dental implants in the aesthetic zone. According to Chappuis et al. (2015), a fully intact buccal bone wall with a thickness greater than 1 millimeter $(\mathrm{mm})$ and a thick gingival biotype are the main requirements to place an immediate implant. When both conditions are present, there is a low recession risk of the buccal gingiva and width reduction of the soft tissue profile at the neck of the implant prosthesis (Buser et al., 2017). However, it should be noted that these conditions are not present in many cases (Januário et al., 2011).

Furthermore, the periodontal ligament plays a major role in the alveolar bone remodelling process. It is able to induce bone resorption and bone formation by the stimulation of osteoblasts and osteoclasts (Liu et al., 2020). The periodontal ligament has an essential nutritional function, which provides irrigation not only to the radicular cement, but also to the inner wall of alveolar bone or lamina dura, originating the complex "lamina dura-periodontal ligament" or "bundle bone" (Cardaropoli et al., 2014). Thus, when tooth loss occurs, the destruction of this complex inevitably results, leading to alveolar bone resorption. Since more "bundle bone" in the buccal wall is present, buccal bone loss is usually greater after tooth extraction (Cardaropoli et al., 2014, 2003).

Over the past two decades, numerous studies have been conducted on different techniques to prevent bone loss after dental extraction, such as the immediate implant insertion (Araújo and Lindhe, 2005; Botticelli et al., 2006), soft tissue augmentation procedures (Puzio et al., 2020; Thoma et al., 2018), palatal orientation of the implant in the socket (Tarnow et al., 2014), the use of platform switching (Linkevicius et al., 2015), and several socket preservation techniques such as "Immediate Dentoalveolar Restoration" (Da Rosa et al., 2019) or "Ice Cream" technique (Tan-Chu et al., 2014), among others (Heinemann et al., 2012). Although all these techniques have certain positive effects on bone preservation, modifications on the peri-implant tissues cannot be completely prevented over time (Esposito et al., 2006; Vignoletti et al., 2012; Esposito et al., 2012; Chen and Buser, 2014; Lin et al., 2014; Avila-Ortiz et al., 2014; Heinemann et al., 2015)

The preservation of dental root to avoid alveolar resorption have been described by different authors, reporting the achievement of aesthetic results after preserving soft tissues (Björn, 1963; Reames et al., 1975; O'Neal et al., 1978; Salama et al., 2007). Based on this concept, a technique called "Socket Shield" (SS) has been described by Hürzeler et al. (2010). The aim of this technique is to maintain the bundle bone on the buccal side, through a partial root extraction, in order to preserve the crestal bone at the original level. Recently, the concept of "Partial Extraction Therapies" (PET) has been described, following the same biological basis. In addition, "Socket-shield" is the most commonly used PET (Gluckman et al., 2016).

Recently, two systematics reviews evaluating current evidence on the SS technique have been published (Gharpure and Bhatavadekar, 2017; Mourya et al., 2019), providing information about results and complications related to this technique. However, both reviews include not only human but also animal studies, without restriction of follow-up time of the different outcomes. Limitations of these reviews are the lack of long-term follow-up data, and the inadequate definition of the outcome analysed, leading to non-homogeneous included studies. Therefore, the aim of the current systematic review is to analyse the mediumand long-term clinical outcomes of the socket shield technique associated with immediate implant placement in human studies. 


\section{Material and methods}

This systematic review was carried out according to Preferred Reporting Items for Systematic Reviews and Meta-Analysis Protocols (PRISMA-P) recommendations (Moher et al., 2010).

\subsection{Focused question}

The following focused PICO (population, intervention, comparison, and outcome) was constructed:

In situations in which tooth extractions may be performed to be replaced by immediate implants, what is the effectiveness of socket shield technique with or without gap filling compared, if possible, to the usual technique (immediate implant) with or without gap filling to avoid the resorption of the alveolar ridge?

\subsection{Eligibility criteria}

\subsubsection{Inclusion criteria}

The inclusion criteria were: (1) Prospective and retrospective observational studies, cross-sectional studies, case-control studies, case series and case reports published in scientific journals; (2) performed in humans older than 18 years; (3) patients in good general health; (4) patients who received socket shield therapy along with the placement of at least one immediate implant in sites presenting ridge deficiencies (maxillary or mandibular incisors, canines and premolars) (5) follow-up of at least one year after treatment; (6) outcome variables evaluating the changes (baseline and at least 12 months follow-up) in the dimension of the alveolar socket; (7) without date restriction; and (8) written in English.

Studies which included interventions aimed for alveolar ridge preservation with the socket shield technique (filling the gap or not) were selected. The selected studies could compare the socket shield technique with other ridge preservation techniques involving immediate implant placement in the aesthetic area.

The primary outcomes were to assess changes between baseline and one year after treatment in the dimension of the alveolar bone using changes in preoperative and postoperative radiographies (cone beam computer tomography (CBCT) or periapical X-ray).

The following secondary outcomes were evaluated: (1) Soft tissue changes through superimposition of preoperative and postoperative plastercasts; (2) aesthetic outcomes evaluating soft tissue recession and pink aesthetic score; (3) implant survival rate, at least 1 year after implant placement; and (4) surgical and prosthetic complications.

\subsubsection{Exclusion criteria}

The exclusion criteria were: (1) in vitro and animal studies, bibliographic and systematic reviews and letters to the editor; (2) studies performing partial extraction therapies different from socket shield technique such as root submergence, pontic shield, proximal socket shield or root membrane technique; (3) studies not available in full text; (4) studies written in a language other than English.

\subsection{Search strategy}

A bibliographic search of the literature was conducted, without restriction of date until December 21, 2020 in the following databases: PubMed/MEDLINE, The Cochrane Library, Scopus and Web of Science. Two independent researchers (LMSA, FFGT) realized the search. The search strategy was the following adapted to each database: (((吕ocket[̈All Fields] AND s̈hield[̈All Fields]) OR (̈ocket[̈All Fields] AND s̈hield[̈All Fields] AND ẗechnique[̈All Fields])) OR (p̈artial[̈All Fields] AND ëxtraction[̈All Fields])) AND (d̈ental implants[̈MeSH Terms] OR (d̈ental[̈All Fields] AND
ïmplants[̈All Fields]) OR d̈ental implants[̈All Fields]). In addition, we performed a review of the references included in the selected articles, to ensure the inclusion of all available studies.

\subsection{Data extraction}

Two independent researchers (LMSA, FGFT) compared search results, to ensure completeness and avoid duplications. They individually screened all full titles and abstracts. All potentially studies were obtained and checked for eligibility using the following abstraction form: first author, journal, centre and country where the study was conducted, title of the paper, type of study, recruitment of patients, inclusion and exclusion criteria, sample characteristics (population, age and gender), characteristics of surgical procedures (number of implants placed, implant brand, surgical technique used in each case), characteristics of the prosthetic restoration (type of provisional and definitive restoration), follow-up time, evaluation of the outcomes, results and complications. In those studies where socket shield technique was compared with another technique, statistical significance was extracted, if available. Any differences in the selection of eligible studies were resolved by discussion with a third reviewer (JCBB).

Moreover, the inter-reviewer reliability (percentage of agreement and kappa correlation coefficient) in full-text analysis was calculated.

\subsection{Risk of bias in individual studies}

Two independent reviewers (OIV, FPG) evaluated the methodological quality of the eligible studies independently. Any disagreement was solved by a third reviewer (LSM).

Cochrane Collaboration tool for assessing risk of bias (Higgins et al., 2011) was used to assess the quality of Randomized Controlled Clinical Trial (RCT). The studies were classified as low risk of bias (low risk of bias for all key domains), unclear risk of bias (unclear risk of bias for 1 or more key domains), and high risk of bias (high risk of bias for 1 or more key domains).

The observational studies were evaluated following the Newcastle-Ottawa Quality Assessment Scale tool (Wells et al., 2000). This tool included a questionnaire divided into 3 categories: Selection (which include 4 questions), Comparability (1 question) and Exposure (3 questions). Each study could obtain a maximum of nine stars. The studies were classified in good, fair or poorquality (GQ FQ or PQ) following the score algorithm proposed by the Agency for Healthcare Research and Quality (McPheeters et al., 2012). Finally, The Joanna Briggs Institute Critical Appraisal tool for case reports (Moola et al., 2015) was used to assess risk of bias for case reports, which included eight questions. A low risk of bias was considered when $\geq 50 \%$ of the answers were "yes", high risk when $\geq 50 \%$ were "no" and uncertain risk of bias if $\geq 50 \%$ of the answers were "unclear".

\section{Results}

\subsection{Inter-reviewer agreement}

The inter-reviewer Cohen's Kappa statistic between the two independent reviewers (L.M.S.A. and F.G.F.T.) was 0.981 (CI 95\%: $0.983 / 0.978$ ). The intervention of a third reviewer for consensus evaluation was not needed.

\subsection{Study selection}

823 articles were found after the initial search, resulting on 538 papers without duplicates. After screening all titles and abstracts, 

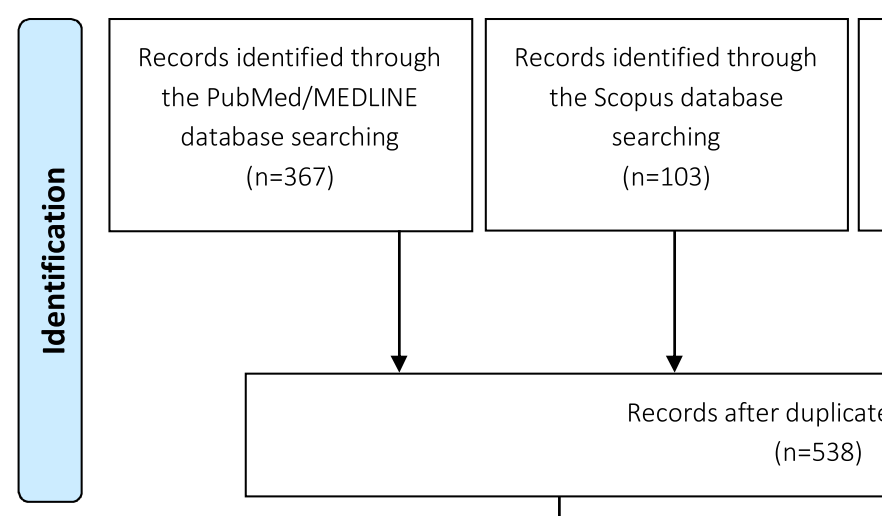
Records identified through the Web of Science database searching $(n=305)$

Records identified through the Cochrane Library database searching $(n=103)$
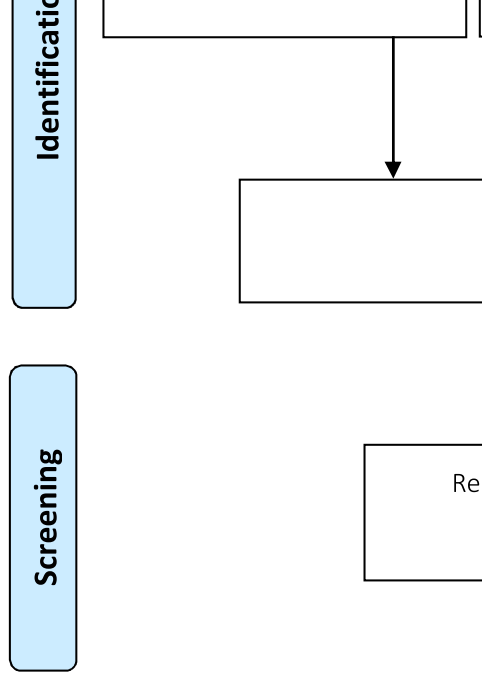

Records after duplicates removed

$$
(n=538)
$$
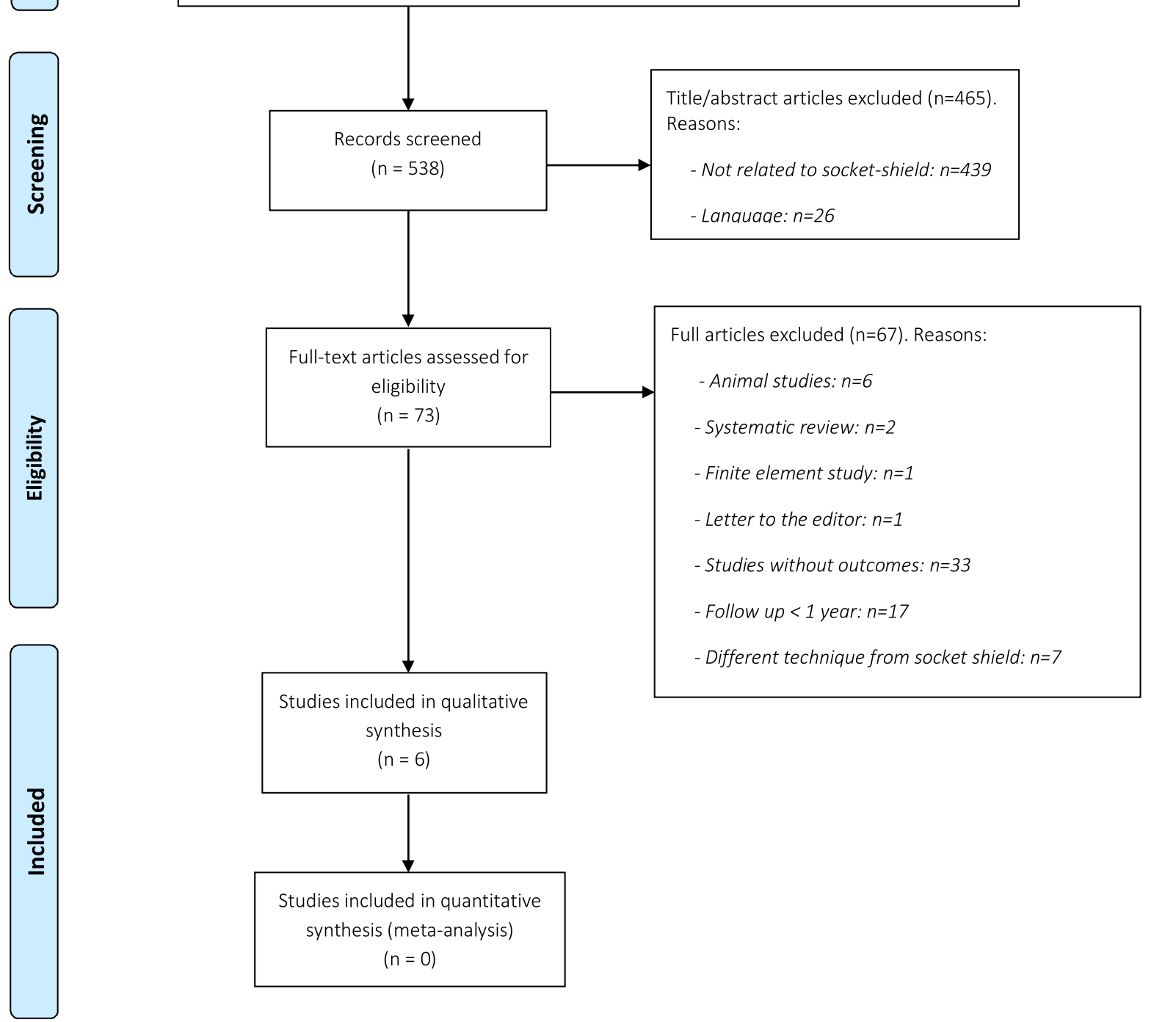

Fig. 1. PRISMA flow diagram of the screening and selection process.

465 articles were excluded: 439 studies for not being related to socket-shield technique, 8 for not being available in full text, and 26 because they were not written in English language. After reading the full text of the 73 selected articles, 67 were discarded due to the following reasons: the studies did not offer the outcomes to be evaluated $(n=33)$, studies with a follow up $<1$ year ( $n=17$ ), animal studies $(n=6)$, studies performing partial extraction therapies different from socket shield technique $(n=7)$, systematic reviews $(n=2)$, finite element study $(n=1)$ and letter to the editor $(n=1)$. Finally, 6 articles were included in this systematic review (Fig. 1).

\subsection{Study characteristics}

The selected studies were: randomized controlled clinical trials $(n=2)$, retrospective studies $(n=1)$ and case reports $(n=3)$. All of them were published between 2017 and 2020. The studies were carried out in different countries: United States, China, Germany, Italy, Turkey and India. They were published in Dentistry journals related to implant dentistry, aesthetics, periodontics, and oral and maxillofacial surgery. All the studies included 69 patients, treated with 69 implants. The characteristics of the studies and the patients included as well as implant placed are shown in Table 1. 
Table 1

Study characteristics.

\begin{tabular}{|c|c|c|c|c|c|}
\hline Author, year, center and country & Type of study & $\begin{array}{l}\text { Number of patients, } \\
\text { sex and age }\end{array}$ & Number of IOI & IOI position & IOI brand \\
\hline $\begin{array}{l}\text { Tiwari et al. (2020) } \\
\text { Dpt of OMFS, Saraswati Dental College and Hospital } \\
\text { Uttar Pradesh, India }\end{array}$ & $\mathrm{RCT}$ & 16 & 16 & Mx anterior region & NA \\
\hline $\begin{array}{l}\text { Aslan (2018) } \\
\text { Private Practice, Izmir, Turkey }\end{array}$ & Case report & $\begin{array}{l}\mathrm{n}=1 \\
\text { Female } \\
32 \text { years }\end{array}$ & 1 & Mx central incisor & $\begin{array}{l}\text { V3, Mis Implant } \\
\text { Technology }\end{array}$ \\
\hline $\begin{array}{l}\text { Guo et al. (2018) } \\
\text { School and Hospital of Stomatology } \\
\text { Jilin, China }\end{array}$ & Case report & $\begin{array}{l}\mathrm{n}=1 \\
1 \text { male } \\
28 \text { years }\end{array}$ & 1 & Mx central incisor & $\begin{array}{l}\text { Straumann Bone } \\
\text { Level SLA Active }\end{array}$ \\
\hline $\begin{array}{l}\text { Bramanti et al. (2018) } \\
\text { University of Messina, } \\
\text { Italy }\end{array}$ & $\mathrm{RCT}$ & $\begin{array}{l}\mathrm{n}=40 \\
\text { Sex and age NA }\end{array}$ & 40 & $\begin{array}{l}\text { From } \mathrm{Mx} / \mathrm{Mn} \text { canine to } \\
\mathrm{Mx} / \mathrm{Mn} \text { canine }\end{array}$ & NA \\
\hline $\begin{array}{l}\text { Bäumer et al. (2017) } \\
\text { Department of Periodontology, Johann-Wolfgang } \\
\text { Goetche University. Frankfturt, Germany }\end{array}$ & $\begin{array}{l}\text { Retrospective } \\
\text { study }\end{array}$ & $\begin{array}{l}\mathrm{n}=10 \\
5 \text { males } \\
5 \text { females } \\
\text { Age NA }\end{array}$ & 10 & $\begin{array}{l}\text { From } 1^{\text {st }} \text { Mx premolar } \\
\text { to } 1^{\text {st }} \mathrm{Mx} \text { premolar }\end{array}$ & $\begin{array}{l}\text { SPI Element } \\
\text { Thommen Medical }\end{array}$ \\
\hline $\begin{array}{l}\text { Roe et al. (2017) } \\
\text { Private clinic } \\
\text { Washington, USA. }\end{array}$ & Case report & $\begin{array}{l}\mathrm{n}=1 \\
1 \text { male } \\
56 \text { years }\end{array}$ & 1 & Mx central incisor & $\begin{array}{l}\text { Nobel Active } \\
\text { (Nobel Biocare) }\end{array}$ \\
\hline
\end{tabular}

$\mathrm{RCT}=$ Randomized Clinical Trial; NA = Not available; $\mathrm{Mx}=$ Maxillary; $\mathrm{Mn}=$ Mandibular

All the implants were placed from 1st maxillary/mandibular premolar to 1 st maxillary/mandibular premolar. Regarding the surgical procedure, 41 implants were placed using the socket-shield technique and 28 using a conventional immediate implant technique. Several implant brands were used among all the studies (see Table 1). The longest follow-up period was found in the article published by Bäumer et al. (2017), with an average follow-up of 58 months, while the minimum follow-up period was observed in the study performed by Aslan (2018) with a follow-up of one year.

Regarding the evaluation methods of the clinical outcomes, dimensional bone changes assessed through $\mathrm{CBCT}$ were reported in three studies (Aslan, 2018; Tiwari et al., 2020; Guo et al., 2018). Marginal bone loss (MBL) by superimposition of preoperative and postoperative digital intraoral radiographs was evaluated in three studies (Bäumer et al., 2017; Roe et al., 2017; Bramanti et al., 2018).

With respect to other secondary outcomes assessed, two studies analysed soft tissue volume alterations through digital superimposition of preoperative and postoperative plaster casts (Bäumer et al., 2017; Aslan, 2018).

Furthermore, two articles reported aesthetic outcomes of the prosthetic restoration throughout Pink Esthetic Furhauser Scale (PEFS) (Bäumer et al., 2017; Bramanti et al., 2018).

The type of prosthetic rehabilitation (provisional or definitive) was detailed in five of the six included studies (Bäumer et al., 2017; Aslan, 2018; Guo et al., 2018; Roe et al., 2017; Bramanti et al., 2018).

Survival rate was detailed only in one of the included studies (Bramanti et al., 2018). Finally, clinical complications during the follow-up period were registered in five of the articles included (Bäumer et al., 2017; Aslan, 2018; Guo et al., 2018; Roe et al., 2017; Bramanti et al., 2018). The previous outcomes are detailed in Table 2.

\subsection{Results of individual studies}

\subsubsection{Surgical procedures}

Among all studies, 28 conventional immediate implants and 41 implants using SS technique were placed. In 20 of the 28 conventional immediate implants, a xenograft was placed into the gap between the implant and the buccal bone plate (Bramanti et al., 2018). In 8 cases, there was not detailed if grafting was performed (Tiwari et al., 2020).
Regarding to the 41 implants placed with the SS technique, in 20 cases implants were placed without using any biomaterial between the implant and the dental fragment (Bramanti et al., 2018). In 13 cases, several techniques were used to fill the gap. In 10 cases, proteins derived from the enamel matrix were placed in the internal part of the vestibular dental fragment (Bäumer et al., 2017). In one case report, a xenograft was placed between the root fragment and the implant (Aslan, 2018). In one case, an allograft was used to fill the gap (Roe et al., 2017) and, in other case report, platelet-rich fibrin (PRF) was placed into the gap (Guo et al., 2018). Finally, in eight cases, there was no data available about grafting between the shield and the implant (Tiwari et al., 2020) (See Table 2).

\subsubsection{Changes in bone dimensions}

Dimensional changes of alveolar bone after SS technique were evaluated through CBCT in three of the included studies (Aslan, 2018; Tiwari et al., 2020; Guo et al., 2018). Tiwari et al. (2020) observed a mean reduction in the thickness of labial bone at crestal position of $0,03 \mathrm{~mm}$ at 12 months post-op with socket shield technique and a mean reduction of $0,187 \mathrm{~mm}$ in the immediate implant placement group, without finding statistically significant differences between groups. Guo et al. (2018) reported a mean horizontal resorption of $0.4 \mathrm{~mm}$ and vertical resorption of $0.4 \mathrm{~mm}, 18$ months after implant placement with SS technique. Furthermore, in the case report published by Aslan (2018) presence of a $0.39 \mathrm{~mm}$ buccal plate width was found one year after socket-shield technique (See Table 2).

\subsubsection{Marginal bone loss (MBL)}

Three of the six included studies (Bäumer et al., 2017; Roe et al., 2017; Bramanti et al., 2018). evaluated MBL with digital periapical radiographs. However, not all of them analyze it in the same way. Bäumer et al. (2017) evaluated this outcome by superimposing of digital periapical radiographs at the interproximal level, resulting in $0.33 \pm 0.43 \mathrm{~mm}$ of bone loss at the mesial level and $0.17 \pm 0.36 \mathrm{~mm}$ at the distal level, after 58 months of follow-up. Performing the same method, Bramanti et al. (2018) evaluated marginal bone resorption between socket-shield technique and immediate implants. After three months, $0.315 \pm 0.047 \mathrm{~mm}$ of bone loss was observed in the socket-shield group and $0.79 \pm 0.084 \mathrm{~mm}$ in the control group, while after three years a marginal reabsorp- 
Table 2

Results of individual studies.

\begin{tabular}{|c|c|c|c|c|c|}
\hline $\begin{array}{l}\text { Author, year, center and } \\
\text { country }\end{array}$ & Surgical procedure & $\begin{array}{l}\text { Prosthetic } \\
\text { rehabilitation }\end{array}$ & Follow-up & Results & Complications \\
\hline $\begin{array}{l}\text { Tiwari et al. (2020) } \\
\text { Dpt of OMFS, Saraswati } \\
\text { Dental College and Hospital } \\
\text { Uttar Pradesh, India }\end{array}$ & $\begin{array}{l}\text { 1st group ( } 8 \mathrm{SS}) \\
\text { 2nd group }(8 \mathrm{CG}) \text { : } \\
\text { Extrac- } \\
\text { tion + immediate } \\
\text { implant }\end{array}$ & NA & 12 months & $\begin{array}{l}\text { CBCT showed more bone loss in CG but } \\
\text { differences between both groups were not } \\
\text { statistically significant. }\end{array}$ & NA \\
\hline $\begin{array}{l}\text { Aslan (2018) } \\
\text { Private Practice, Izmir, } \\
\text { Turkey }\end{array}$ & $\begin{array}{l}\text { SS and gap filled } \\
\text { with xenograft } \\
\text { (Bio-Oss, Geistlich). }\end{array}$ & $\begin{array}{l}\text { 1st screw retained } \\
\text { acrylic crown. } \\
\text { 2nd lithium disilicate } \\
\text { crown cemented on } \\
\text { lithium disilicate } \\
\text { abutment cemented on } \\
\text { Ti-base ( } 8 \text { months after } \\
\text { provisional } \\
\text { restoration). }\end{array}$ & 12 months & $\begin{array}{l}\text { 1. Volumetric alteration (digital overlap of pre } \\
\text { and post digital impressions): } \\
\text { - Palatal side showed more volumetric changes } \\
\text { compared to the buccal side in all the } \\
\text { measures performed. } \\
\text { 2. CBCT showed presence of a } 0,39 \mathrm{~mm} \text { buccal } \\
\text { bone plate at } 1 \text { year. }\end{array}$ & No complications \\
\hline $\begin{array}{l}\text { Guo et al. (2018) } \\
\text { School and Hospital of } \\
\text { Stomatology } \\
\text { Jilin, China }\end{array}$ & $\mathrm{SS}+\mathrm{PRF}$ in the gap. & $\begin{array}{l}\text { 2nd stage } 24 \text { weeks } \\
\text { after IOI insertion. } \\
\text { No provisional } \\
\text { restoration. } \\
\text { Final restoration: } \\
\text { porcelain-fused to } \\
\text { metal crown. }\end{array}$ & 18 months & $\begin{array}{l}\text { CBCT showed } 0.4 \mathrm{~mm} \text { horizontal bone loss and } \\
0.4 \mathrm{~mm} \text { vertical bone loss } 18 \mathrm{~m} \text { after implant } \\
\text { placement. }\end{array}$ & No complications \\
\hline $\begin{array}{l}\text { Bramanti et al. (2018) } \\
\text { University of Messina, } \\
\text { Italy }\end{array}$ & $\begin{array}{l}\text { 1st group (20 SS) } \\
\text { 2nd group ( } 20 \mathrm{CG}) \text { : } \\
\text { Extrac- } \\
\text { tion+immediate } \\
\text { implant + allograft } \\
\text { (CopiOs, Zimmer) } \\
\text { in the gap. }\end{array}$ & $\begin{array}{l}\text { 1st immediate acrylic } \\
\text { resin provisional above } \\
\text { an acetate abutment. } \\
2 \text { nd Screw-retained } \\
\text { zirconia crown. }\end{array}$ & 35 months & $\begin{array}{l}\text { 1. Marginal bone loss (superimposition of pre } \\
\text { and post intraoral radiographs) after } 3 \text { years: } \\
\text { - SS: } 0.605 \pm 0.06 \mathrm{~mm} \\
\text { - CG: } 1.115 \pm 0.131 \mathrm{~mm} \\
\text { - p }=0.00014 \\
\text { 2. Aesthetic outcomes (PEFS) after } 3 \text { years: } \\
\text { - SS: } 12.15 \pm 0.87 \\
\text { - CG: } 10.3 \pm 1.59 \\
\text { - p value }=0,00008 \\
\text { 3. Survival rate (Buser criteria): } 100 \% \text { of cases. }\end{array}$ & No complications \\
\hline $\begin{array}{l}\text { Bäumer et al. (2017) } \\
\text { Department of } \\
\text { Periodontology, } \\
\text { Johann-Wolfgang Goetche } \\
\text { University. Frankfturt, } \\
\text { Germany }\end{array}$ & $\begin{array}{l}\text { SS + Emdogain } \\
\text { (Straumann) inside } \\
\text { the root fragment. }\end{array}$ & $\begin{array}{l}1^{\text {st }} \text { immediate acrylic } \\
\text { provisional ( } 4 \text { cases) or } \\
\text { healing abutment ( } 6 \\
\text { cases). } \\
2^{\text {nd }} \text { Custom Zirconia } \\
\text { abutment and } \\
\text { lithium disilicate } \\
\text { crowns. ( } 6 \text { cases } \\
\text { screw-retained and } 4 \\
\text { cases cemented). }\end{array}$ & 51-63 months & $\begin{array}{l}\text { 1. Marginal Bone loss (superimposition of pre } \\
\text { and post digital intraoral radiographs): } \\
\text { - Mesial: }-0.33 \pm 0.43 \mathrm{~mm} \\
\text { - Distal: }-0.17 \pm 0.36 \mathrm{~mm} \\
\text { 2. Soft tissue volume alterations (digital } \\
\text { superimposition of pre and post plaster cast): } \\
\text { - Oro-facial: } 0.37 \pm 0.23 \mathrm{~mm} \\
\text { - Mid-facial recession: } 0.33 \pm 0.23 \mathrm{~mm} \\
\text { - Recession at neighboring teeth: } \\
0.38 \pm 0.27 \mathrm{~mm} \\
\text { 3. Aesthetic outcomes (PEFS): } \\
\text { - Mean score: } 12\end{array}$ & No complications \\
\hline $\begin{array}{l}\text { Roe et al. (2017) } \\
\text { Private clinic } \\
\text { Washington, USA. }\end{array}$ & $\begin{array}{l}\text { Modified SS: facial } \\
\text { window approach } \\
\text { and gap filled with } \\
\text { allograft (Puros, } \\
\text { Zimmer Dental) } \\
\text { and collagen } \\
\text { membrane } \\
\text { (Bio-Guide, } \\
\text { Geistlich Pharma). }\end{array}$ & $\begin{array}{l}1^{\text {st }} \text { immediate acrylic } \\
\text { resin provisional crown } \\
\text { above a titanium } \\
\text { temporary abutment. } \\
2^{\text {nd }} \text { metal ceramic } \\
\text { crown cemented on } \\
\text { custom abutment ( } 6 \\
\text { months later). }\end{array}$ & 24 months & $\begin{array}{l}\text { 1. Marginal Bone loss evaluation through } \\
\text { periapical X-ray and CBCT showed clinical and } \\
\text { radiological stability between baseline and } 6 \\
\text { months, } 12 \text { months and } 24 \text { months. (Measures } \\
\text { NA) }\end{array}$ & No complications \\
\hline
\end{tabular}

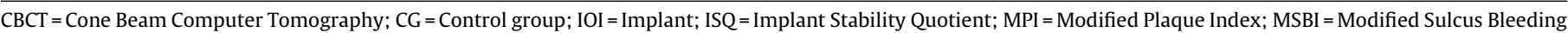
Index; NA = Not available; PEFS = Pink Esthetic Furhauser Scale; PPD = Pocket Probing Depths; PRF = Platelet-rich fibrin; SS = Socket shield.

tion of $0.605 \pm 0.06 \mathrm{~mm}$ was recorded for the socket-shield group and $1.115 \pm 0.131 \mathrm{~mm}$ in the control group. Therefore, statistically significant differences between comparison groups were found at six months and also at three years. Finally, in the study performed by Roe et al. (2017), radiological stability of marginal bone level was found between baseline and 24 months after implant placement, although authors do not provide data about this outcome (See Table 2).

\subsubsection{Soft tissue changes}

Changes in soft tissues evaluated through digital superimposition of preoperative and postoperative plaster casts were evaluated in two studies (Bäumer et al., 2017; Aslan, 2018). However, the volume changes were evaluated with different techniques. Aslan (2018) measurements were performed in the bucco-palatal direc- tion parallel to the implant axis in three slices: 1,4 , and $7 \mathrm{~mm}$ below the gingival margin, finding more volumetric changes in the palatal side compared to the buccal side in each slice at different levels. Baumet et al. (2017) assessed these differences focusing only on the buccal aspect. A vestibular loss of $0.37 \pm 0.23 \mathrm{~mm}$ was observed, and also an apical migration of the gingival margin at the implant level of $0.33 \pm 0.23 \mathrm{~mm}$ and a recession of $0.38 \pm 0.27 \mathrm{~mm}$ respect to the adjacent teeth. (See Table 2)

\subsubsection{Aesthetic outcomes}

Two studies reported aesthetic outcomes of the prosthetic restoration throughout PEFS (Bäumer et al., 2017; Bramanti et al., 2018), finding in all cases treated with socket-shield technique higher aesthetic results. Bramanti et al. (2018) found better results in the SS group compared to the control group while Bäumer et al. 
(2017) observed a mean score of 12 in all cases included, which means high aesthetic result (See Table 2).

\subsubsection{Survival rate}

Survival rate was only recorded by Bramanti et al. (2018), finding a survival rate of $100 \%$ after 35 months of implant placement in the SS group.

\subsubsection{Prosthetic restoration}

In three of the included studies, provisional resin acrylic screwretained restorations were placed the same day of the implant placement (Bäumer et al., 2017; Aslan, 2018; Roe et al., 2017; Bramanti et al., 2018). In one study, no provisional restoration was placed (Guo et al., 2018) and one study (Tiwari et al., 2020) did not provide information about provisional prosthetic restoration. A great heterogeneity not only in materials used for the final rehabilitations but also in techniques and final loading time was found in the included studies (See Table 2).

\subsubsection{Complications}

Five of the included studies reported the possible complications (Bäumer et al., 2017; Aslan, 2018; Guo et al., 2018; Roe et al., 2017; Bramanti et al., 2018), but no complications were registered during the follow-up period in any of the cases included. (see Table 2)

\subsection{Risk of bias of the studies individually}

As shown in Table 3 both RCTs included in this review (Tiwari et al., 2020; Bramanti et al., 2018). showed unclear risk of bias according to Cochrane Collaboration (Higgins et al., 2011), while all the observational studies and case reports bias assessed through Newcastle-Ottawa (Wells et al., 2000) (Table 4) and JBI (Moola et al., 2015) (Table 5) quality assessment showed a low risk of bias.

\section{Discussion}

\subsection{Summary of evidence}

The objective of this systematic review was to analyze the medium- and long-term clinical outcomes of human studies of the socket shield technique associated with immediate implant placement. To our knowledge, no previous systematic reviews including only human clinical studies have been carried out. Analysing the results of the six included studies, it is not possible to confirm that this socket shield technique is a predictable alternative approach to the simple placement of immediate implants. In spite of that it has been observed that it is able to enhance the maintenance of the dimensions of the alveolar bone, reduces the risk of marginal bone loss, and improves the aesthetic, there is not consistent data yet to recommend this technique as alternative treatment with the same long-terms predictability as conventional immediate implants.

The primary objective of this study was to assess changes in the dimension of the alveolar bone after socket shield technique. This outcome has been evaluated through different methods in the included studies. Studies evaluating changes in bone dimensions through CBCT showed lower rates of horizontal and vertical alveolar bone resorption than simple placement of immediate implants (Guo et al., 2018). It was also observed that maintenance of the buccal plate after at least one year with the socket shield technique was better than with placement of only immediate implants (Aslan, 2018; Tiwari et al., 2020).

None of the two previous mentioned systematic reviews about socket shield evaluated this outcome (Gharpure and Bhatavadekar, 2017; Mourya et al., 2019), so it is not possible to compare our results with previous data about this technique. However, according to systematic reviews evaluating changes in the dimension of the alveolar bone after conventional immediate implants the values obtained varied between $0.5-1 \mathrm{~mm}$ horizontal and vertical resorption after one year (Lee et al., 2014) and similar values of width and height on buccal bone plate (Clementini et al., 2015). As bundle bone is preserved with socket shield technique, it is expected to achieve better results when compared to conventional immediate implants.

\subsection{Marginal bone loss}

Studies which evaluated MBL through intraoral radiographs obtained values between $0.17-0.33 \mathrm{~mm}$ of bone resorption after 58 months of performing socket shield technique (Bäumer et al., 2017), while studies analysing differences in marginal bone loss between socket shield and immediate implants showed statistically significant differences between groups, finding better results in the socket shield group after two- and three-years follow-up (Bramanti et al., 2018). Comparing these findings with conventional immediate implants, two systematic reviews showed marginal bone loss values of $0,05-1,37 \mathrm{~mm}$ at one year follow up (Sommer et al., 2020) and 0,4-2,06 $\mathrm{mm}$ after 12-60 months (Cosyn et al., 2019). Therefore, in terms of MBL, as well as changes in bone dimensions, the socket shield technique seems to prevent bone resorption in the medium-long term follow-up with similar efficacy to conventional immediate implants.

\subsection{Soft tissue volume and aesthetic outcomes}

Soft tissue volume showed good results after socket shield technique (Bäumer et al., 2017; Aslan, 2018), even finding better results in the socket shield group when compared to conventional immediate implants (Bramanti et al., 2018). These findings led to register high aesthetic results in all the studies which evaluated aesthetic outcomes (Bäumer et al., 2017; Bramanti et al., 2018). These data are in accordance not only with previous systematic reviews about the socket shield technique (Mourya et al., 2019), but also with systematic reviews evaluating these clinical outcomes in conventional immediate implants (Clementini et al., 2015). As periodontal ligament as well as buccal plate is maintained with the socket shield technique, soft tissue volume seems to be also preserved as the inserting dentogingival fibers are not detached and therefore, good aesthetic results can be achieved with this technique.

\subsection{Surgical procedures}

Regarding the surgical technique, a lack of homogeneity among the included studies was observed. In this sense, further investigations on many aspects of the socket shield technique should be carried out to provide a validated protocol, such as length and width of the root fragment, and need for grafting to fill the gap. The original technique described by Hürzeler et al. (2010) recommended to keep the root fragment $1 \mathrm{~mm}$ above the buccal plate to preserve periodontal fibres. It has been observed that this could led to direct contact between the crown or abutment and the coronal portion of the root fragment, then stimulating peri-implant mucosa inflammation and triggering complications such as internal or external exposure of the shield (Gluckman et al., 2018). In order to avoid these complications, Gluckman et al. (2018) recommended reduce the fragment to the bone level and create an internal beveled chamfer in the crestal aspect to provide more space for soft tissue infill in the prosthetic emerging transgingival portion. Neither proper length nor width of the root fragment have been established yet. Calvo-Guirado et al. (2019) conducted an 
Table 3

Quality assessment of RCTs using the Cochrane Collaboration recommendations.

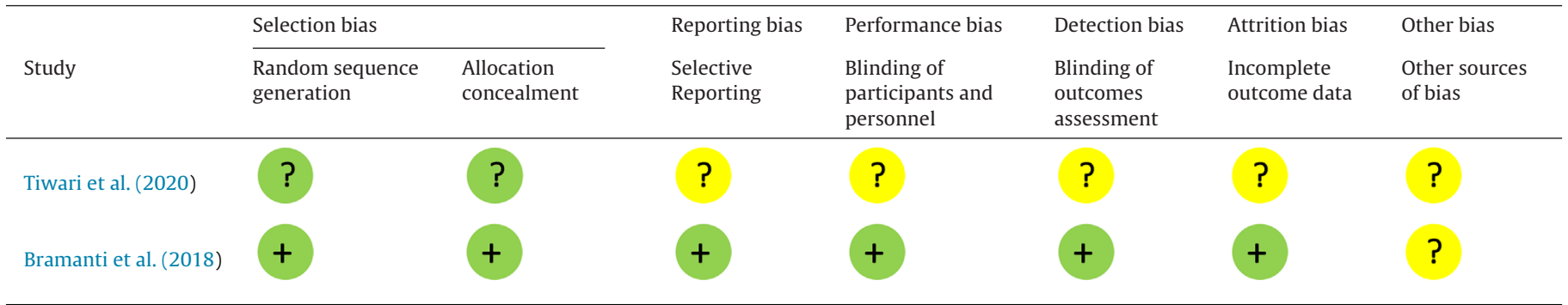

+= Low risk of bias; - = High risk of bias; ? = Unclear.

Table 4

Quality assessment of observational studies using the Newcastle-Ottawa scale.

\begin{tabular}{ll} 
& $\begin{array}{l}\text { Bäumer et al. } \\
(2017)\end{array}$ \\
\hline SELECTION & $*$ \\
- Representativeness of the exposed cohort & $*$ \\
- Selection of the non-exposed cohort & $*$ \\
- Ascertainment of exposure & $*$ \\
- Demonstration that outcome of interest was not present & \\
$\quad$ at start of study & \\
& \\
COMPARABILITY & \\
- Study controls for socket shield group & \\
- Study control for any additional factor (duration of & \\
exposure) & $*$ \\
OUTCOME & $*$ \\
- Assessment of outcome & $*$ \\
- Was follow-up long enough for outcomes to occur? & \\
- Adequacy of follow up of cohorts & $\mathbf{7}$ \\
NEWCASTLE-OTTAWA SCORE &
\end{tabular}

animal study evaluating the influence of the length of the root fragment, finding a lack of bone formation and migration of connective tissue in root fragments longer than $2 \mathrm{~mm}$. Moreover, they found new bone formation when enough space was created between the dental fragment and the implant (Calvo-Guirado et al., 2016). Similar results were found by Bäumer et al. (2017), who found not only bone formation but also a healthy periodontal ligament on the buccal side. In this sense, there is no consensus on grafting the gap between the implant and the root fragment or, on the contrary, placing the implant in direct contact with the socket shield. It seems that creating space between the root and the implant could provide not only better results due to the new bone formation, but also preventing complications, such as placing the implant in direct contact with the root could increase tooth fracture risk promoting implant failure. Therefore, it appears to be more recommended to maintain a gap between the socket shield and the implant. Nevertheless, there is no agreement in terms of filling the gap or not. The results of this systematic review showed a great heterogeneity about this topic, finding 20 cases without grafting the gap (Bramanti et al., 2018) and 13 cases in which different biomaterials were used (Bäumer et al., 2017; Aslan, 2018; Guo et al., 2018; Roe et al., 2017). As for conventional immediate implants, the tendency in socket shield is grafting the gap when it is $>1 \mathrm{~mm}$ (Botticelli et al., 2006). However, it has not been determined which is the best material to use. Based on the current histological evidence, the application on enamel matrix protein in the internal aspect of the root fragment seems to improve treatment prognosis as new cementum is formed on the inside of the root, which could prevent resorption and future complications (Hürzeler et al., 2010; Bäumer et al., 2017). These results are in accordance with the findings obtained in the systematic review published by Mourya et al. (2019).

\subsection{Complications}

None of the included studies reported complications in a followup period of 12-58 months, disagreeing with the current evidence. Mourya et al. (2019) observed a 6.96\% implant failure rate in human clinical studies with a 426 implants sample with a follow-up period range of 5-58 months, while a previous systematic review performed by Gharpure and Bhatasvadekar (2017) found a $24.26 \%$ failure rate (33 implants of a total sample of 136 implants placed with the socket shield technique with a follow up period of 4-58 months). Crestal bone loss around the implants (78.78\%) and shield exposure (15.15\%) were the main complications found by Gharpure and Bhatavadekar (2017). Furthermore, Gluckman et al. (2018) reported the greatest rate of complications associated with the Socket Shield Technique, such as implant failure, finding $19.5 \%$ failure rate in a total of 128 cases with a follow-up of at least four years. Besides, in this study, there were 16 shield exposures, five implant osseointegration failures, three failures due to infection and one implant migration. Due to this huge complication rate, most of the studies agree that this technique should be performed by an advanced experienced clinician (Mourya et al., 2019; Gluckman et al., 2018, 2019).

Studies performing conventional immediate implants showed a lower complication rate when compared with the socket shield technique (Del Fabbro et al., 2019; Pigozzo et al., 2018). This is a key aspect to consider when thinking about this technique as an alternative option in implant treatment. Therefore, more long-term clinical studies about socket-shield are needed to support advantages of this technique.

Furthermore, long-term prognosis of the remaining tooth fragment is uncertain because periodontal ligament response and buccal bone stability have not been widely studied yet. This point is crucial because it may directly affect the survival and the prognosis of the implant and the restoration. For this reason, future studies on the socket shield technique should focus on the long-term prognosis of the root fragment and its effect on the technique.

\subsection{Prosthetic management}

A great variability of materials and techniques for prosthetic rehabilitation was found among the included studies. Therefore, it is not possible to establish conclusions and prosthetic protocols after socket shield technique with the results obtained in this systematic review. The tendency observed in the included studies was to provisionalize when it is possible, in order to maintain gingival architecture as recommended after conventional immediate implant placement (Morton et al., 2018). As previously mentioned, the most common complication reported was internal exposure (Gluckman et al., 2018), which means a direct contact between the crown or abutment and the coronal portion of the root fragment. In order to avoid this complication, the prosthetic step-by-step protocol published by Gluckman et al. (2019) recommended to perform a 
Table 5

Quality assessment of case reports using the Joanna Briggs Institute Critical Appraisal tools.

\begin{tabular}{|c|c|c|c|}
\hline Study & Aslan (2018) & Guo et al. (2018) & Roe et al. (2017) \\
\hline Were patient's demographic characteristics clearly described? & + & + & + \\
\hline Was the patient's history clearly described and presented as a timeline? & + & + & - \\
\hline Was the current clinical condition of the patient on presentation clearly described? & + & + & + \\
\hline Were diagnostic tests or assessment methods and the results clearly described? & + & + & + \\
\hline Was the intervention or treatment procedure clearly described? & + & + & + \\
\hline Was the post-intervention clinical condition clearly described? & + & - & + \\
\hline Were adverse events (harms) or unanticipated events identified and described? & + & + & + \\
\hline Does the case report provide takeaway lessons? & + & + & + \\
\hline
\end{tabular}

$+=$ Yes; $-=$ No; = Unclear.

narrow-designed abutment with an expanding S-Shape curve that ensure ample space for soft tissue as well as avoid contact with the root fragment.

\subsection{Limitations}

Despite the promising results observed in this review, some limitations must be taken into account to reach firm conclusions. Search strategy registered only studies published in English, so some information might not be included. There are also few longterm RCT comparing socket shield with conventional immediate implants. Hence, to recommend this technique as an alternative treatment to conventional immediate implants is not possible. Moreover, a lack of homogeneity was found not only in evaluation methods but also in surgical technique and prosthetic management of the studies analysed. Therefore, a consistent approach based on standardized clinical research is required.

Finally, all the included studies in this systematic review were uneventful. However, previous clinical studies in the literature show that failure and complication rates are high (Gluckman et al., 2018).

\section{Conclusions}

According to the results observed in this systematic review, socket shield technique seems to be a good technique in terms of alveolar bone maintenance, marginal bone stability and aesthetic outcomes in immediate implant treatment. However, a lack of consensus not only in surgical technique but also in prosthetic management was observed. Therefore, based on current evidence, it is not possible to recommend this technique as an alternative treatment with the same long-term predictability as conventional immediate implants. Further studies clarifying the long-term results and prevention of complications when performing socket shield technique are needed.

\section{Funding}

This research did not receive any specific grant from funding agencies in the public, commercial, or not-for-profit sectors.

\section{Ethical statement}

Not applicable

\section{Conflict of interests}

The authors declare that they have no conflict of interests.

\section{References}

Buser, D., Chappuis, V., Belser, U.C., Chen, S., 2017. Implant placement post extraction in esthetic single tooth sites: when immediate, when early, when late? Periodontol 200073 (1), 84-102, http://dx.doi.org/10.1111/prd.12170.
Araújo, M.G., Lindhe, J., 2005. Dimensional ridge alterations following tooth extraction. An experimental study in the dog. J. Clin. Periodontol. 32 (2), 212-218, http://dx.doi.org/10.1111/j.1600-051X.2005.00642.x.

Araújo, M.G., da Silva, J., de Mendonça, A.F., Lindhe, J., 2015. Ridge alterations following grafting of fresh extraction sockets in man. A randomized clinical trial. Clin. Oral Imp. Res. 26 (4), 407-412, http://dx.doi.org/10.1111/clr.12366.

Aslan, S., 2018. Improved volume and contour stability with thin socket-shield preparation in immediate implant placement and provisionalization in the esthetic zone. Int. J. Esthet. Dent. 13 (2), 172-183.

Avila-Ortiz, G., Elangovan, S., Kramer, K.W., Blanchette, D., Dawson, D.V., 2014. Effect of alveolar ridge preservation after tooth extraction: a systematic review and meta-analysis. J. Dent. Res. 93, 950-958, http://dx.doi.org/10.1177/ 0022034514541127.

Bäumer, D., Zuhr, O., Rebele, S., Hürzeler, M., 2017. Socket Shield Technique for immediate implant placement-clinical, radiographic and volumetric data after 5 years. Clin. Oral Imp. Res. 28 (11), 1450-1458, http://dx.doi.org/10.1111/clr. 13012.

Björn, H., 1963. Free transplantation of gingival propria. Sven. Tandlak. Tidskr. 22, 684.

Botticelli, D., Persson, L.G., Lindhe, J., Berglundh, T., 2006. Bone tissue formation adjacent to implants placed in fresh extraction sockets: an experimental study in dogs. Clin. Oral Imp. Res. 17 (4), 351-358, http://dx.doi.org/10.1111/j.16000501.2006.01270.x.

Bramanti, E., Norcia, A. Cicciù, M., Matacena, G. Cervino, G., Troiano, G et al. 2018. Postextraction dental implant in the aesthetic zone, socket shield technique versus conventional protocol. J. Craniofac. Surg. 29 (4), 1037-1041, http://dx. doi.org/10.1097/SCS.0000000000004419.

Calvo-Guirado, J.L., Troiano, M., López-López, P.J., Ramírez-Fernandez, M.P., de Val, J., Marin, J., Gehrke, S.A., 2016. Different configuration of socket shield technique in peri-implant bone preservation: an experimental study in dog mandible. Ann. Anat. 208, 109-115, http://dx.doi.org/10.1016/j.aanat.2016.06.008.

Calvo-Guirado, J.L., Benítez-García, J.A., Maté Sánchez de Val, J.E., Pérez-Albacete Martínez, C., Gehrke, S.A., Delgado-Ruiz, R., et al., 2019. Socket-shield technique: the influence of the length of the remaining buccal segment of healthy tooth structure on peri-implant bone and socket preservation. A study in dogs. Ann. Anat. 221, 84-92, http://dx.doi.org/10.1016/j.aanat.2018.09.003.

Cardaropoli, G., Araújo, M., Lindhe, J., 2003. Dynamics of bone tissue formation in tooth extraction sites. An experimental study in dogs. J. Clin. Periodontol. 30 (9), 809-818, http://dx.doi.org/10.1034/j.1600-051x.2003.00366.x.

Cardaropoli, D., Gaveglio, L., Gherlone, E., Cardaropoli, G., 2014. Soft tissue contour changes at immediate implants: a randomized controlled clinical study. Int. J. Periodontics Restorative Dent. 34 (5), 631-637, http://dx.doi.org/10.11607/prd. 1845.

Chappuis, V., Engel, O., Shahim, K., Reyes, M., Katsaros, C., Buser, D., 2015. Soft tissue alterations in esthetic postextraction sites: a 3-dimensional analysis. J. Dent. Res. 94 (9), 187S-193S, http://dx.doi.org/10.1177/0022034515592869.

Chen, S.T., Buser, D., 2014. Esthetic outcomes following immediate and early implant placement in the anterior maxilla-a systematic review. Int. J. Oral Maxillofac. Implants 29, 186-215, http://dx.doi.org/10.11607/jomi.2014suppl.g3.3.

Clementini, M., Tiravia, L., De Risi, V., Vittorini Orgeas, G., Mannocci, A., de Sanctis, M. 2015. Dimensional changes after immediate implant placement with or without simultaneous regenerative procedures: a systematic review and meta-analysis. J. Clin. Periodontol. 42 (7), 666-677, http://dx.doi.org/10.1111/jcpe.12423.

Cosyn, J., De Lat, L., Seyssens, L., Doornewaard, R., Deschepper, E., Vervaeke, S., 2019. The effectiveness of immediate implant placement for single tooth replacement compared to delayed implant placement: a systematic review and meta-analysis. J. Clin. Periodontol. 46, 224-241, http://dx.doi.org/10.1111/jcpe. 13054.

da Rosa, J., Pértile de Oliveira Rosa, A.C., Huwais, S., 2019. Use of the immediate dentoalveolar restoration technique combined with osseodensification in periodontally compromised extraction sites. Int. J. Periodontics Restorative Dent. 39 (4), 527-534, http://dx.doi.org/10.11607/prd.3883.

Del Fabbro, M., Testori, T., Kekovic, V, Goker, F., Tumedei, M., Wang H.L., 2019. A systematic review of survival rates of osseointegrated implants in fully and partially edentulous patients following immediate loading. J. Clin. Med. 8 (12), 2142, http://dx.doi.org/10.3390/jcm8122142.

Esposito, M., Grusovin, M.G., Coulthard, P., Worthington, H.V., 2006. The efficacy of various bone augmentation procedures for dental implants: a cochrane systematic review of randomized controlled clinical trials. Int. J. Oral Maxillofac. Implants 21 (5), 696-710. 
Esposito, M., Maghaireh, H., Grusovin, M.G., Ziounas, I., Worthington, H.V., 2012. Soft tissue management for dental implants: what are the most effective techniques? A cochrane systematic review. Eur. J. Oral Implantol. 5 (3), 221-238.

Gharpure, A.S., Bhatavadekar, N.B., 2017. current evidence on the socket-shield technique: a systematic review. J. Oral Implantol. 43 (5), 395-403, http://dx.doi.org/ 10.1563/aaid-joi-D-17-00118.

Gluckman, H., Salama, M., Du Toit, J., 2016. Partial Extraction Therapies (PET) part 1: maintaining alveolar ridge contour at pontic and immediate implant sites. Int. J. Periodontics Restorative Dent. 36 (5), 681-687, http://dx.doi.org/10.11607/prd. 2783.

Gluckman, H., Salama, M., Du Toit, J., 2018. A retrospective evaluation of 128 socketshield cases in the esthetic zone and posterior sites: partial extraction therapy with up to 4 years follow-up. Clin. Implant Dent. Relat. Res. 20 (2), 122-129, http://dx.doi.org/10.1111/cid.12554.

Gluckman, H., Nagy, K., Du Toit, J., 2019. Prosthetic management of implants placed with the socket-shield technique. J. Prosthet. Dent. 121 (4), 581-585, http://dx. doi.org/10.1016/j.prosdent.2018.06.009.

Guo, T., Nie, R., Xin, X., Wang, H., Qi, M., Yu, K., et al., 2018. Tissue preservation through socket-shield technique and platelet-rich fibrin in immediate implant placement: a case report. Medicine 97 (50), e13175, http://dx.doi.org/10.1097/ MD.0000000000013175.

Heinemann, F., Hasan, I., Schwahn, C., Bourauel, C., Mundt, T., 2012. Bone level change of extraction sockets with Bio-Oss collagen and implant placement: a clinical study. Ann. Anat. 194 (6), 508-512, http://dx.doi.org/10.1016/j.aanat.2011.11. 012.

Heinemann, F., Hasan, I., Bourauel, C., Biffar, R., Mundt, T., 2015. Bone stability around dental implants: treatment related factors. Annals of anatomy. Ann. Anat. 199, 3-8, http://dx.doi.org/10.1016/j.aanat.2015.02.004.

Higgins, J.P., Altman, D.G., Gøtzsche, P.C., Jüni, P., Moher, D., Oxman, A., et al., 2011. The cochrane collaboration's tool for assessing risk of bias in randomised trials. BMJ 343, d5928, http://dx.doi.org/10.1136/bmj.d5928.

Hürzeler, M.B., Zuhr, O., Schupbach, P., Rebele, S.F., Emmanouilidis, N., Fickl, S., 2010. The socket-shield technique: a proof-of-principle report. J. Clin. Periodontol. 37 (9), 855-862, http://dx.doi.org/10.1111/j.1600-051X.2010.01595.x.

Januário, A.L., Duarte, W.R., Barriviera, M., Mesti, J.C., Araújo, M.G., Lindhe, J., 2011. Dimension of the facial bone wall in the anterior maxilla: a cone-beam computed tomography study. Clin. Oral Imp. Res. 22 (10), 1168-1171, http://dx.doi.org/10. 1111/j.1600-0501.2010.02086.x.

Lang N.P. Zitzmann, N.U., Working Group 3 of the VIII European Workshop on Periodontologyce:surname>, 2012. Clinical research in implant dentistry: evaluation of implant-supported restorations, aesthetic and patient-reported outcomes. J. Clin. Periodontol. 39 (12), 133-138, http://dx.doi.org/10.1111/j. 1600-051X.2011.01842.x.

Lee, C.T., Chiu, T.S., Chuang, S.K., Tarnow, D., Stoupel, J., 2014. Alterations of the bone dimension following immediate implant placement into extraction socket: systematic review and meta-analysis. J. Clin. Periodontol. 41 (9), 914-926, http:// dx.doi.org/10.1111/jcpe.12276.

Lin, G.H., Chan, H.L., Bashutski, J.D., Oh, T.J., Wang, H.L., 2014. The effect of flapless surgery on implant survival and marginal bone level: a systematic review and meta-analysis. J. Periodontol. 85 (5), e91-e103, http://dx.doi.org/10.1902/jop. 2013.130481.

Linkevicius, T., Puisys, A., Steigmann, M., Vindasiute, E., Linkeviciene, L., 2015. Influence of vertical soft tissue thickness on crestal bone changes around implants with platform switching: a comparative clinical study. Clin. Implant Dent. Relat. Res. 17 (6), 1228-1236, http://dx.doi.org/10.1111/cid.12222.

Liu, J., Zhao, Z., Ruan, J., Weir, M.D., Ma, T., Ren, K., et al., 2020. Stem cells in the periodontal ligament differentiated into osteogenic, fibrogenic and cementogenic lineages for the regeneration of the periodontal complex. J. Dent. 92, 103259, http://dx.doi.org/10.1016/j.jdent.2019.103259.

McPheeters, M.L., Kripalani, S., Peterson, N.B., Idowu, R.T., Jerome, R.N., Potter, S.A, et al., 2012. Closing the quality gap: revisiting the state of the science (vol. 3: quality improvement interventions to address health disparities). Evid. Rep. Technol. Assess, 1-475 (208.3)

Moher, D., Liberati, A., Tetzlaff, J., Altman, D.G., PRISMA Group, 2010. Preferred reporting items for systematic reviews and meta-analyses: the PRISMA statement. Int. J. Surg. 8 (5), 336-341, http://dx.doi.org/10.1016/j.ijsu.2010.02.007.
Moola, S., Munn, Z., Sears, K., Sfetcu, R., Currie, M., Lisy, K., et al., 2015. Conducting systematic reviews of association (etiology): the Joanna Briggs Institute's approach. Int. J. Evid. Healthc. 13 (3), 163-169, http://dx.doi.org/10.1097/XEB. 0000000000000064.

Morton, D., Gallucci, G., Lin, W.S., Pjetursson, B., Polido, W., Roehling, S., et al., 2018. Group 2 ITI consensus report: prosthodontics and implant dentistry. Clin. Oral Imp. Res. 29 (16), 215-223, http://dx.doi.org/10.1111/clr.13298.

Mourya, A., Mishra, S.K., Gaddale, R., Chowdhary, R., 2019. Socket-shield technique for implant placement to stabilize the facial gingival and osseous architecture: a systematic review. J. Invest. Clin. Dent. 10, e12449, http://dx.doi.org/10.1111/ jicd.12449.

O'Neal, R.B., Gound, T., Levin, M.P., del Rio, C.E., 1978. Submergence of roots for alveolar bone preservation. I. Endodontically treated roots. Oral Surg. Oral Med. Oral Pathol. 45 (5), 803-810, http://dx.doi.org/10.1016/0030-4220(78)90158-5.

Pigozzo, M.N., Rebelo da Costa, T., Sesma, N., Laganá, D.C., 2018. Immediate versus early loading of single dental implants: a systematic review and meta-analysis. J. Prosthet. Dent. 120 (1), 25-34, http://dx.doi.org/10.1016/j.prosdent.2017.12. 006.

Puzio, M., Hadzik, J., Błaszczyszyn, A., Gedrange, T., Dominiak, M., 2020. Soft tissue augmentation around dental implants with connective tissue graft (CTG) and xenogenic collagen matrix (XCM). 1-year randomized control trail. Ann. Anat. 230, 151484, http://dx.doi.org/10.1016/j.aanat.2020.151484.

Reames, R.L., Nickel, J.S., Patterson, S.S., Boone, M., el-Kafrawy, A.H., 1975. Clinical, radiographic, and histological study of endodontically treated retained roots to preserve alveolar bone. J. Endod. 1, 367-373, http://dx.doi.org/10.1016/S00992399(75)80212-3.

Roe, P., Kan, J., Rungcharassaeng, K., 2017. Residual root preparation for socket-shield procedures: a facial window approach. Int. J. Esthet. Dent. 12 (3), 324-335.

Salama, M., Ishikawa, T., Salama, H., Funato, A., Garber, D., 2007. Advantages of the root submergence technique for pontic site development in esthetic implant therapy. Int. J. Periodontics Restorative Dent. 27 (6), 521-527.

Schropp, L., Wenzel, A., Kostopoulos, L., Karring, T., 2003. Bone healing and soft tissue contour changes following single-tooth extraction: a clinical and radiographic 12-month prospective study. Int. J. Periodontics Restorative Dent. 23 (4), 313-323.

Sommer, M., Zimmermann, J., Grize, L., Stübinger, S., 2020. Marginal bone loss one year after implantation: a systematic review of different loading protocols. Int. J. Oral Maxillofac. Surg. 49 (1), 121-134, http://dx.doi.org/10.1016/j.ijom.2019 03.965.

Tan-Chu, J.H., Tuminelli, F.J., Kurtz, K.S., Tarnow, D.P., 2014. Analysis of buccolingual dimensional changes of the extraction socket using the ïce cream coneflapless grafting technique. Int. J. Periodontics Restorative Dent. 34 (3), 399-403, http:// dx.doi.org/10.11607/prd.1605.

Tarnow, D.P., Chu, S.J., Salama, M.A., Stappert, C.F., Salama, H., Garber, D.A., et al., 2014. Flapless postextraction socket implant placement in the esthetic zone: part 1. The effect of bone grafting and/or provisional restoration on facial-palatal ridge dimensional change-a retrospective cohort study. Int. J. Periodontics Restorative Dent. 34 (3), 323-331, http://dx.doi.org/10.11607/prd.1821.

Thoma, D.S., Naenni, N., Figuero, E., Hämmerle, C., Schwarz, F. Jung, R.E., et al., 2018. Effects of soft tissue augmentation procedures on peri-implant health or disease: a systematic review and meta-analysis. Clin. Oral Imp. Res. 29 (Suppl 15), 32-49, http://dx.doi.org/10.1111/clr.13114.

Tiwari, S., Bedi, R.S., Wadhwani, P., Aurora, JK Chauhan, H., 2020 Comparison of immediate implant placement following extraction with and without socketshield technique in esthetic region. J. Oral Maxillofac. Surg. 19 (4), 552-560, http://dx.doi.org/10.1007/s12663-019-01272-3.

Vignoletti, F., Matesanz, P., Rodrigo, D., Figuero, E., Martin, C., Sanz, M., 2012. Surgical protocols for ridge preservation after tooth extraction. A systematic review. Clin. Oral Imp. Res. 23 (5), 22-38, http://dx.doi.org/10.1111/j.1600-0501.2011.02331. $\mathrm{x}$.

Wells, G., Shea, B., O’Connell, D., Peterson, J., 2000. The NewcastleOttawa Scale (NOS) for Assessing the Quality of Nonrandomised Studies in Meta-analyses. Ottawa Hospital Research Institute, Ottawa http://www.ohri.ca/pro-grams/ clinical_epidemiology/oxford.asp. 